Check for updates

Cite this: RSC Adv., 2017, 7, 26487

Received 6th April 2017

Accepted 11th May 2017

DOI: $10.1039 / \mathrm{c} 7 \mathrm{ra03939e}$

rsc.li/rsc-advances

\title{
Direct conversion of carbohydrates to diol by the combination of niobic acid and a hydrophobic ruthenium catalyst $\uparrow$
}

\author{
Ying Duan, ${ }^{\text {ab }}$ Jun Zhang, ${ }^{a}$ Dongmi Li, ${ }^{a}$ Dongsheng Deng, ${ }^{a}$ Lu-Fang Ma ${ }^{a}$ \\ and Yanliang Yang iD *a
}

\begin{abstract}
Tetrahydro-2,5-furandimethanol (THFDM) was obtained directly from a wide variety of carbohydrates by the combination of niobic acid and a hydrophobic ruthenium catalyst. Fructose, glucose, and polysaccharides consisting of fructose or glucose could be converted to THFDM in one-step. The selectivity to THFDM was kept around $60 \%$ while the glucose conversion varied from $9 \%$ to $49 \%$. The assynthesized niobic acid was characterized by TEM, $\mathrm{N}_{2}$ adsorption/desorption, XRD, $\mathrm{NH}_{3}-\mathrm{TPD}$ and FT-IR spectra of adsorpted pyridine. The niobic acid was proved to have medium and strong acid sites with a high Brönsted/Lewis ratio, which played a great role for keeping high THFDM selectivity using glucose as a substrate.
\end{abstract}

\section{Introduction}

Production of chemicals and fuels from carbohydrates is an attractive way for alleviating the shortage of non-renewable fossil resources. ${ }^{1-5}$ One of the main strategies for the valorization of carbohydrates is the synthesis of platform compounds and their high value transformation. The conversion of carbohydrates to platform compounds such as 5-(hydroxymethyl) furfural (HMF), ${ }^{6-10}$ furfural, ${ }^{11-13}$ levulic acid (LA $)^{14,15}$ and the utilization of platform compounds have both been extensively researched. Furfuryl alcohol, ${ }^{16-20}$ tetrahydrofurfuryl alcohol, ${ }^{21,22}$ dimethylfuran, ${ }^{23} \quad 2,5$-furandicarboxylic acid, ${ }^{24}$ diformylfuran, ${ }^{25-31}$ cyclopentanone, ${ }^{32,33} \gamma$-valerolactone, ${ }^{14,34-36}$ and tetrahydro-2,5-furandimethanol ${ }^{37,38}$ are the typical target products.

Considering that the platform compounds such as HMF are not stable and not easy to be separated, purified and stored, the conversion of carbohydrates to target products in one pot has attracted attention increasingly. ${ }^{39-47}$ A large number of works have been reported on the direct carbohydrate conversion. Sen and his co-workers gave reports on the direct conversion of fructose to 2,5-dimethyltetrahydrofuran or 5-methylfurfural by using $\mathrm{RhCl}_{3}$ as the hydrogenation catalyst and $\mathrm{HI}$ as acid promoter. ${ }^{45}$ Sels et al. obtained high yields of liquid straightchain alkanes directly from cellulosic feedstock in an one-pot biphasic catalytic system. ${ }^{\mathbf{4 6}}$

${ }^{a}$ Henan Key Laboratory of Function-Oriented Porous Material, College of Chemistry and Chemical Engineering, Luoyang Normal University, Luoyang 471934, P. $R$. China. E-mail: yangyl0410@126.com

${ }^{b}$ College of Food and Drug, Luoyang Normal University, Luoyang 471934, China

$\dagger$ Electronic supplementary information (ESI) available. See DOI: 10.1039/c7ra03939e
Alcohols, including monobasic alcohols and diols, are important chemical products from fossil resources. The carbohydrates are ideal renewable raw materials for the production of monobasic alcohols and diols as they contain a large amount of alcohol hydroxyl. ${ }^{48-56} \mathrm{~A}$ lot of research had been reported on this topic. For example, hexanols could be produced in high yield by conversion of cellulose over $\mathrm{Ir}-\mathrm{ReO}_{x} /$ $\mathrm{SiO}_{2}$ catalyst in biphasic reaction system. ${ }^{56}$ And 1,5-pentanediol could be obtained in high yield from biomass via furfural and tetrahydrofurfuryl alcohol. ${ }^{55}$

Tetrahydro-2,5-furandimethanol (THFDM) is a valuable diol that can be used as solvent or monomer ${ }^{57}$ and also could be converted to 1,6 -hexanediol, ${ }^{58}$ an important monomer in the plastics industry, in very high yield. Recently, we achieved the direct conversion of fructose to tetrahydro-2,5-furandimethanol (THFDM) by the combination of Amberlyst-15 and hydrophobic $\mathrm{Ru} / \mathrm{SiO}_{2}-\mathrm{TM}$ in a water/cyclohexane biphasic system. ${ }^{7}$ However, the reported procedure was only effective for the conversion of fructose, a monosaccharide not common in nature.

In this article, we reported a catalytic system which was able to provide THFDM directly from glucose, the monomer of most of the carbohydrates rich in nature. Based on this, we proved that this catalytic system was able to directly convert many kinds of carbohydrates including sucrose and starch to THFDM. The conversion of carbohydrates was illuminated in Scheme 1. The carbohydrates were first dehydrated to HMF in water phase on acids catalyst and then the HMF was hydrogenated to THFDM in oil phase on hydrophobic ruthenium catalyst. The hydrophobicity of ruthenium catalyst kept the ruthenium catalyst in oil phase. As a result the hydrogenation of carbohydrates under $\mathrm{H}_{2}$ and the degradation of HMF were both avoided. 


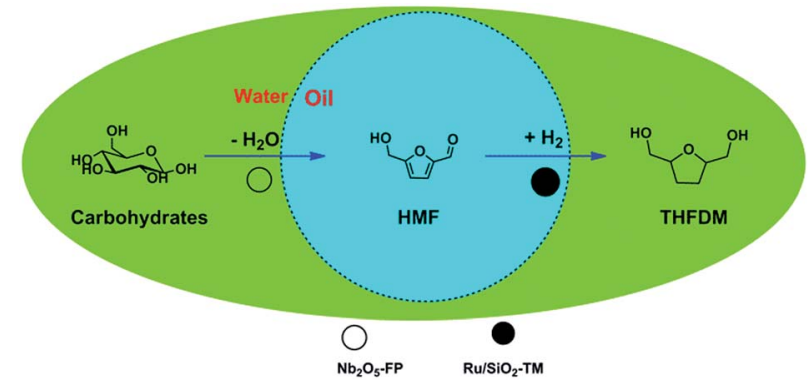

Scheme 1 Conversion of carbohydrates into THFDM in the water/ cyclohexane biphasic system.

\section{Material and methods}

\section{Materials}

All chemicals were of analytical grade and used as received unless otherwise stated. Inulin, sucrose, maltose, cellobiose, starch (soluble) and zirconium oxychloride were obtained from Aladdin Chemistry Co. Ltd. Fructose, glucose, and HF were purchased from Tianjin Kemiou Chemical Reagent Co. Ltd. Amberlyst-70 was obtained from Dow Chemical Shanghai Co. Ltd. $\mathrm{RuCl}_{3}(\mathrm{Ru} 37 \%)$ was purchased from Shenyang Research Institute of Nonferrous Metal. HY-zeolite $(\mathrm{Si} / \mathrm{Al}=5)$ was purchased from Nankai University Catalyst Co. Ltd. China. Niobium oxide was obtained from UCB Pharma. Pyridine and toluene were redistilled before used. All other reagents were commercially available.

\section{Preparation of catalysts}

The $\mathrm{SiO}_{2}(4.00 \mathrm{~g})$ was dispersed in the solution of $\mathrm{RuCl}_{3}\left(\mathrm{RuCl}_{3}\right.$ : $542.1 \mathrm{mg}, 2.00 \mathrm{mmol}, \mathrm{H}_{2} \mathrm{O}: 24.00 \mathrm{~g}$ ). The mixture was stirred and kept at room temperature for $12 \mathrm{~h}$ and then dried at $393 \mathrm{~K}$ for $6 \mathrm{~h}$. Before used, the catalyst was reduced at $673 \mathrm{~K}$ by $\mathrm{H}_{2}$ for $2 \mathrm{~h}$ and then passivated in $1 \% \mathrm{O}_{2} / \mathrm{N}_{2}$ at room temperature to afford $\mathrm{Ru} / \mathrm{SiO}_{2}$. The $\mathrm{Ru} / \mathrm{SiO}_{2}-\mathrm{TM}$ catalyst was prepared by $\mathrm{CH}_{3}$ functionalization of $\mathrm{Ru} / \mathrm{SiO}_{2} \cdot \mathrm{Ru} / \mathrm{SiO}_{2}(2.00 \mathrm{~g})$ was transferred into a $100 \mathrm{~mL}$ round flask to which toluene $(40 \mathrm{~mL})$, then trimethylchlorosilane $(10 \mathrm{~mL})$ and pyridine $(10 \mathrm{~mL})$ were introduced. The mixture refluxed under $\mathrm{N}_{2}$ for $24 \mathrm{~h}$, and then filtered and washed with alcohol for five times. The resulted solid were dried at $323 \mathrm{~K}$ in vacuum overnight.

$\mathrm{Nb}_{2} \mathrm{O}_{5}(1.00 \mathrm{~g})$ was added into $\mathrm{H}_{3} \mathrm{PO}_{4}$ aqueous solution (30 $\mathrm{mL}, 0.5 \mathrm{M}$ ) and stirred for $8 \mathrm{~h}$ at $343 \mathrm{~K}$. Then the precipitation was washed with water $(50 \mathrm{~mL} \times 3$ times $)$ and dried overnight at $393 \mathrm{~K}$. The resulted white powder was calcined in air at $573 \mathrm{~K}$ for $3 \mathrm{~h}$ to afford the $\mathrm{H}_{3} \mathrm{PO}_{4}$-treated niobic acid $\left(\mathrm{Nb}_{2} \mathrm{O}_{5}-\mathrm{P}\right)$.

$\mathrm{Nb}_{2} \mathrm{O}_{5}(10.00 \mathrm{~g})$ was added in $\mathrm{HF}$ aqueous solution $(45 \mathrm{~mL}$, $40 \mathrm{wt} \%$ ). The mixture was stirred at $353 \mathrm{~K}$ for $24 \mathrm{~h}$ to afford a clear solution. Then concentrated ammonia water was added drop wise to adjust the $\mathrm{pH}$ 8-9 under drastic stirring. The precipitation was centrifuged and washed with ammonia water for 6 times. The solid was dried at $393 \mathrm{~K}$ to afford niobic acid. The $\mathrm{H}_{3} \mathrm{PO}_{4}$-treated procedure was the same as the preparation of $\mathrm{Nb}_{2} \mathrm{O}_{5}-\mathrm{P}$ to afford the $\mathrm{Nb}_{2} \mathrm{O}_{5}-\mathrm{FP}$.
$\mathrm{ZrOCl} \cdot 8 \mathrm{H}_{2} \mathrm{O}(16.20 \mathrm{~g})$ was dissolved in water $(100 \mathrm{~mL})$. Then concentrated ammonia water was added drop wise to adjust the pH 8-9 under drastic stirring. After kept stand for $24 \mathrm{~h}$ at room temperature, the precipitation was centrifuged and washed with water until no $\mathrm{Cl}^{-}$was detected by $\mathrm{AgNO}_{3}$. The precipitation was dried at $373 \mathrm{~K}$ to afford zirconium hydroxide solid. Then the zirconium hydroxide was impregnated by $\mathrm{H}_{2} \mathrm{SO}_{4}\left(1 \mathrm{~mol} \mathrm{~L}^{-1}\right)$ under vigorous stirring at room temperature for $4 \mathrm{~h}$. After centrifuged, the precipitation was dried at $393 \mathrm{~K}$ overnight and calcined at $773 \mathrm{~K}$ for $4 \mathrm{~h}$ to afford the $\mathrm{SO}_{4}{ }^{2-} / \mathrm{ZrO}_{2}$.

\section{Characterization of catalysts}

Fourier transform infrared (FT-IR) spectra were collected on a Bruker Tensor 27 FT-IR spectrometer in KBr media. Samples were thoroughly dried before measured.

The X-ray powder diffraction (XRD) patterns were obtained using Rigaku D/Max 2500/PC powder diffractometer with $\mathrm{Cu} \mathrm{K \alpha}$ radiation $(\lambda=0.15418 \mathrm{~nm})$ at $40 \mathrm{kV}$ and $200 \mathrm{~mA}$ in a scanning rate of $5^{\circ} \min ^{-1}$.

The transmission electron microscopy (TEM) was conducted on a JEOLJEM-2000EX electron microscopy.

$\mathrm{N}_{2}$ physical adsorption/desorption measurement was carried out at liquid nitrogen temperature on an Autosorb-1 Quantachrome instrument. Samples were pre-degassed at $300{ }^{\circ} \mathrm{C}$ for about $10 \mathrm{~h}$ to remove water and other physical adsorbed species.

Temperature-programmed desorption of ammonia $\left(\mathrm{NH}_{3}-\right.$ TPD) was performed on a Micromeritics AutoChem II 2920 Instrument with a thermal conductivity detector (TCD). The catalyst was degassed at $673 \mathrm{~K}$ in an atmosphere of Ar.

The FT-IR spectra for pyridine adsorption of the catalyst were conducted on a Bruker Tensor 27 FT-IR spectrometer. Prior to pyridine adsorption, the catalyst was evacuated in vacuum at $523 \mathrm{~K}$. After that, the sample was used for the background reference collected. Subsequently, pulses of pyridine were introduced in an in situ cell for adsorption. Then the catalyst was heated to $523 \mathrm{~K}$ and evacuated for $30 \mathrm{~min}$. The spectra of the catalysts were collected after the reaction cell was cooled to room temperature.

\section{Catalytic reactions}

The catalytic reactions were performed in a $60 \mathrm{~mL}$ stainless steel autoclave equipped with a magnetic stirrer, a pressure gauge, and automatic temperature control apparatus. The reactor was connected to a hydrogen cylinder for reaction pressure. In a typical experiment, an aqueous solution of carbohydrates (3 $\mathrm{mL}, 1.00 \mathrm{mmol}$ by monosaccharide), cyclohexane $(6 \mathrm{~mL})$, and catalysts were put into the reactor. After sealing and purging with $\mathrm{H}_{2}$ for 4 times to exclude air, the autoclave was heated to the desired temperature, and then $\mathrm{H}_{2}(4 \mathrm{MPa})$ was charged into the reactor. The magnetic agitator was set to $1200 \mathrm{rpm}$ to start the reaction. After reaction, the autoclave was cooled. The aqueous phase and oil phase were sampled and analyzed respectively. After sampling ethanol was added to make the acid and $\mathrm{Ru} / \mathrm{SiO}_{2}-\mathrm{TM}$ in one phase. The catalysts were centrifuged 
and washed with $50 \mathrm{~mL}$ ethanol for 3 times. After dried at $373 \mathrm{~K}$ under vacuum overnight, the catalyst was used for the next run.

\section{Products analysis}

The products were identified by Agilent $6890 \mathrm{~N}$ GC/5973MS as well as by comparison with the retention times to corresponding standards in GC and HPLC traces. The amounts of products were determined based on GC and HPLC data. Gas chromatography measurements were conducted on Agilent 6890A GC. HP-5 capillary column $(30 \mathrm{~m} \times 530 \mu \mathrm{m} \times 1.5 \mu \mathrm{m})$ was used for separation of reaction mixtures. 1,2,4,5-Tetramethylbenzene (TMB) was used as the internal standard. HPLC analysis was carried out using a Waters e2695 HPLC system equipped with a 2414 refractive index detector maintained at $303 \mathrm{~K}$. The aqueous sample was separated using a Waters Sugar-Pak 1 column $(6.5 \mathrm{~mm} \times 30 \mathrm{~cm})$ at $358 \mathrm{~K}$, using ethylenediaminetetraacetic acid calcium disodium salt hydrate (EDTACa) aqueous solution $\left(50 \mathrm{mg} \mathrm{L}^{-1}\right)$ as the mobile phase at a flow rate of $0.55 \mathrm{~mL} \mathrm{~min}^{-1}$. The conversion and selectivity of main products were evaluated as below:

$$
\text { Conversion } \begin{aligned}
(\%)= & \left(1-\frac{\text { moles of substrate }}{\text { moles of substrate loaded initially }}\right) \\
& \times 100 \%
\end{aligned}
$$

Selectivity $(\%)=\frac{\text { moles of products }}{\text { moles of substrate converted }} \times 100 \%$

\section{Results and discussion}

We focused our attentions on the selection of different kinds of acid using glucose as the starting material. The HY, A-70, $\mathrm{H}_{2} \mathrm{SO}_{4}, \mathrm{SO}_{4}{ }^{2-} / \mathrm{ZrO}_{2}$ and $\mathrm{Nb}_{2} \mathrm{O}_{5}$ were selected as acids. The result was exhibited in Fig. 1. The acids were first used in the conversion of glucose to HMF (Fig. 1a). All the acids except $\mathrm{Nb}_{2} \mathrm{O}_{5}$-FP gave poor selectivity to HMF while the $\mathrm{Nb}_{2} \mathrm{O}_{5}-\mathrm{FP}$ had $78 \%$ selectivity to HMF after $1 \mathrm{~h}$. And the selectivity of HMF was $56 \%$ after $4 \mathrm{~h}$ with $27 \%$ conversion of glucose. The results showed that the $\mathrm{Nb}_{2} \mathrm{O}_{5}-\mathrm{PF}$ was an effective solid acid for the conversion of glucose to HMF as reported in the literature. ${ }^{59}$ When the acids were used in the conversion of glucose to THFDM, $\mathrm{HY}, \mathrm{A}-70, \mathrm{H}_{2} \mathrm{SO}_{4}, \mathrm{SO}_{4}{ }^{2-} / \mathrm{ZrO}_{2}$ resulted poor selectivity of THFDM (no more than $20 \%$ Fig. $1 \mathrm{~b}$ ) in the experiment range. This was attributed to the poor selectivity of HMF from glucose when those acids were used as the catalyst (Fig. 1a). The selectivity of THFDM is positively correlated to the selectivity of HMF on the specific acid. The selectivity of THFDM increased to $31 \%$ with $35 \%$ glucose conversion when $\mathrm{H}_{3} \mathrm{PO}_{4}$-treated niobic acid $\left(\mathrm{Nb}_{2} \mathrm{O}_{5}-\mathrm{P}\right)$ was employed. Surprisingly, the selectivity of THFDM increased significantly to $64 \%$ when $\mathrm{H}_{3} \mathrm{PO}_{4}$-treated fresh niobic acid $\left(\mathrm{Nb}_{2} \mathrm{O}_{5}-\mathrm{PF}\right)$ was used, in spite of the conversion of glucose was only $9 \%$ after $1 \mathrm{~h}$. When the reaction time was extended to $4 \mathrm{~h}$, the selectivity of THFDM was $63 \%$ at $32 \%$ glucose conversion. The fresh niobic acid was prepared by dissolution of
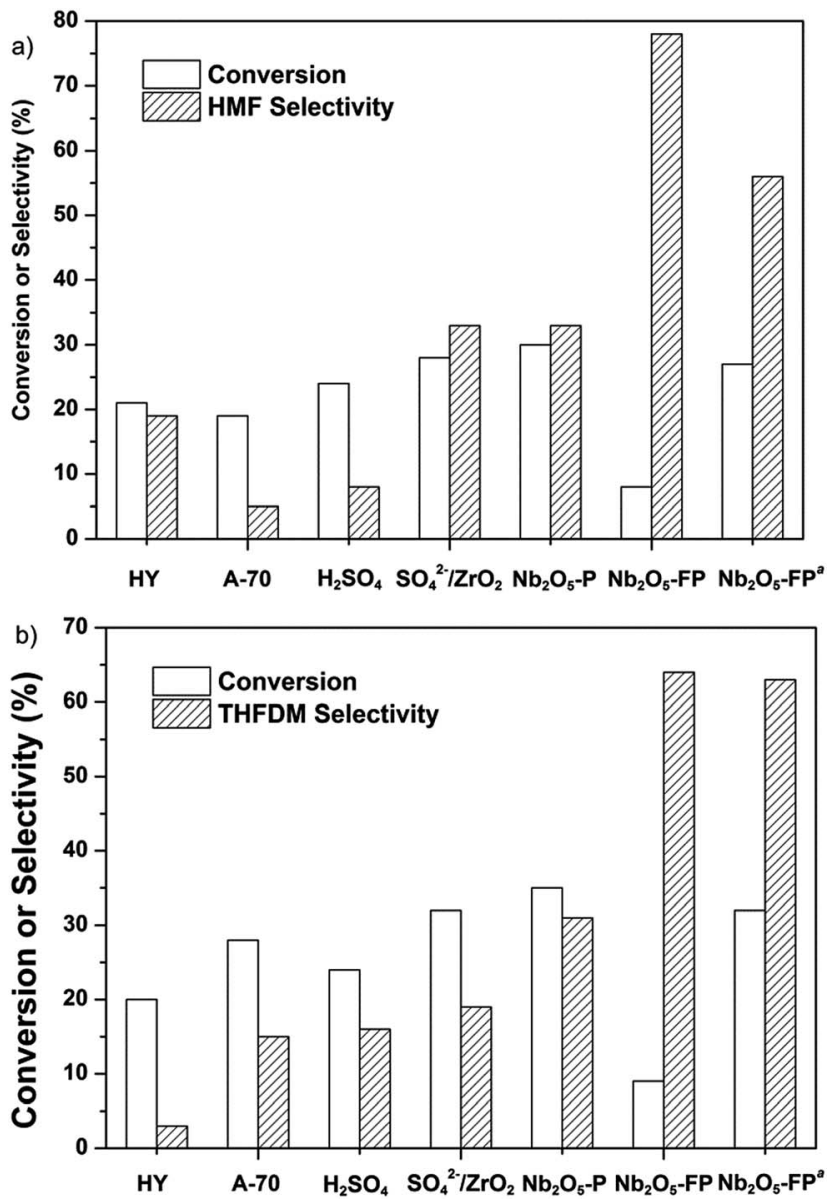

Fig. 1 The conversion of glucose by (a) acids (b) $\mathrm{Ru} / \mathrm{SiO}_{2}-\mathrm{TM}$ and acids. Reaction conditions: acids ( $40 \mathrm{mg}$ ), glucose aqueous solution (3 $\mathrm{mL}$, glucose $1 \mathrm{mmol})$, cyclohexane $(6 \mathrm{~mL}), \mathrm{H}_{2}(4 \mathrm{MPa}), 433 \mathrm{~K}, 1 \mathrm{~h} . \mathrm{Ru} /$

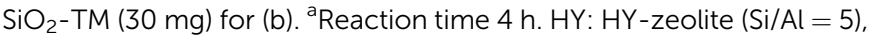
A-70: Amberlyst-70.

niobium oxide and then precipitated by aqueous ammonia. And the $\mathrm{Nb}_{2} \mathrm{O}_{5}-\mathrm{FP}$ was used in subsequence reactions.

The performance of $\mathrm{Nb}_{2} \mathrm{O}_{5}$-FP was further studied by carrying out the reaction in two cases. The case I was the conversion of glucose to HMF under $\mathrm{H}_{2}$ atmosphere by just using the $\mathrm{Nb}_{2} \mathrm{O}_{5}$ - $\mathrm{FP}$ as the catalyst. And the combination of $\mathrm{Nb}_{2} \mathrm{O}_{5}-\mathrm{FP}$ and $\mathrm{Ru} / \mathrm{SiO}_{2}-\mathrm{TM}$ was used for the other case named case II. The conversion-time profiles of both cases were almost the same as shown in Fig. 2. This should be ascribed to the hydrophobicity of the $\mathrm{Ru} / \mathrm{SiO}_{2}-\mathrm{TM}$. The $\mathrm{Ru} / \mathrm{SiO}_{2}-\mathrm{TM}$ was kept in the oil phase where there had no glucose. Thus, the conversion of glucose was catalyzed by $\mathrm{Nb}_{2} \mathrm{O}_{5}-\mathrm{FP}$ in both cases which led to the same conversion of glucose at the same reaction time.

The products selectivity versus glucose conversion was shown in Fig. 3. Very high selectivity of HMF was obtained at the initial stage for the case I (Fig. 3b). Meanwhile, $24 \%$ selectivity of fructose was gained in this case. It showed that the $\mathrm{Nb}_{2} \mathrm{O}_{5}-\mathrm{PF}$ was able to convert glucose to fructose. With the time prolonged the selectivity of fructose decreased to $3 \%$. This was caused by the conversion of fructose to HMF. However, the selectivity of HMF decreased sharply from $76 \%$ to $27 \%$, revealing that the 


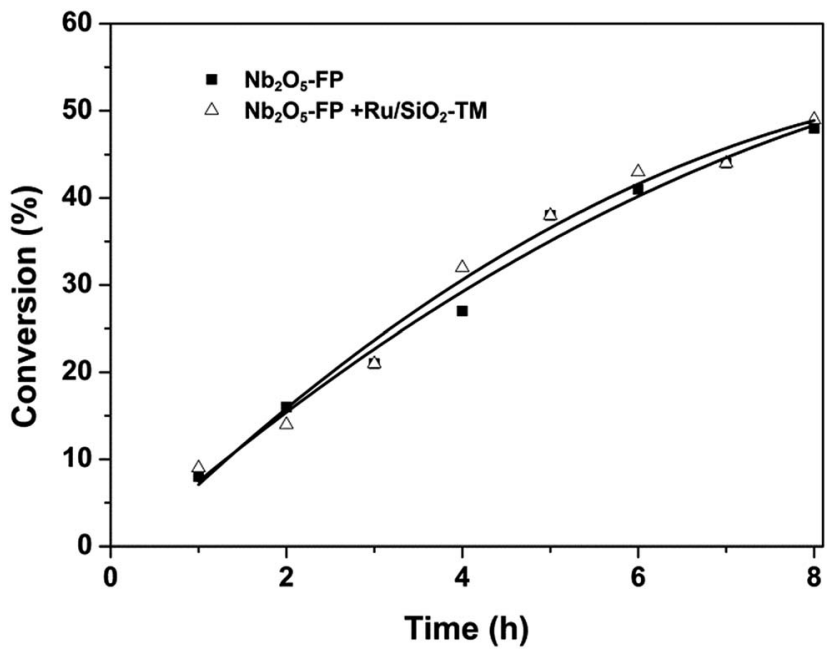

Fig. 2 Conversion-time profiles of glucose dehydration to HMF and glucose conversion to THFDM. Reaction conditions: $\mathrm{Nb}_{2} \mathrm{O}_{5}-\mathrm{FP}$ (40 $\mathrm{mg})$, glucose aqueous solution ( $3 \mathrm{~mL}$, glucose $1 \mathrm{mmol})$, cyclohexane (6 $\mathrm{mL}), \mathrm{H}_{2}(4 \mathrm{MPa}), 433 \mathrm{~K} . \Delta: \mathrm{Ru} / \mathrm{SiO}_{2}-\mathrm{TM}(30 \mathrm{mg})$.
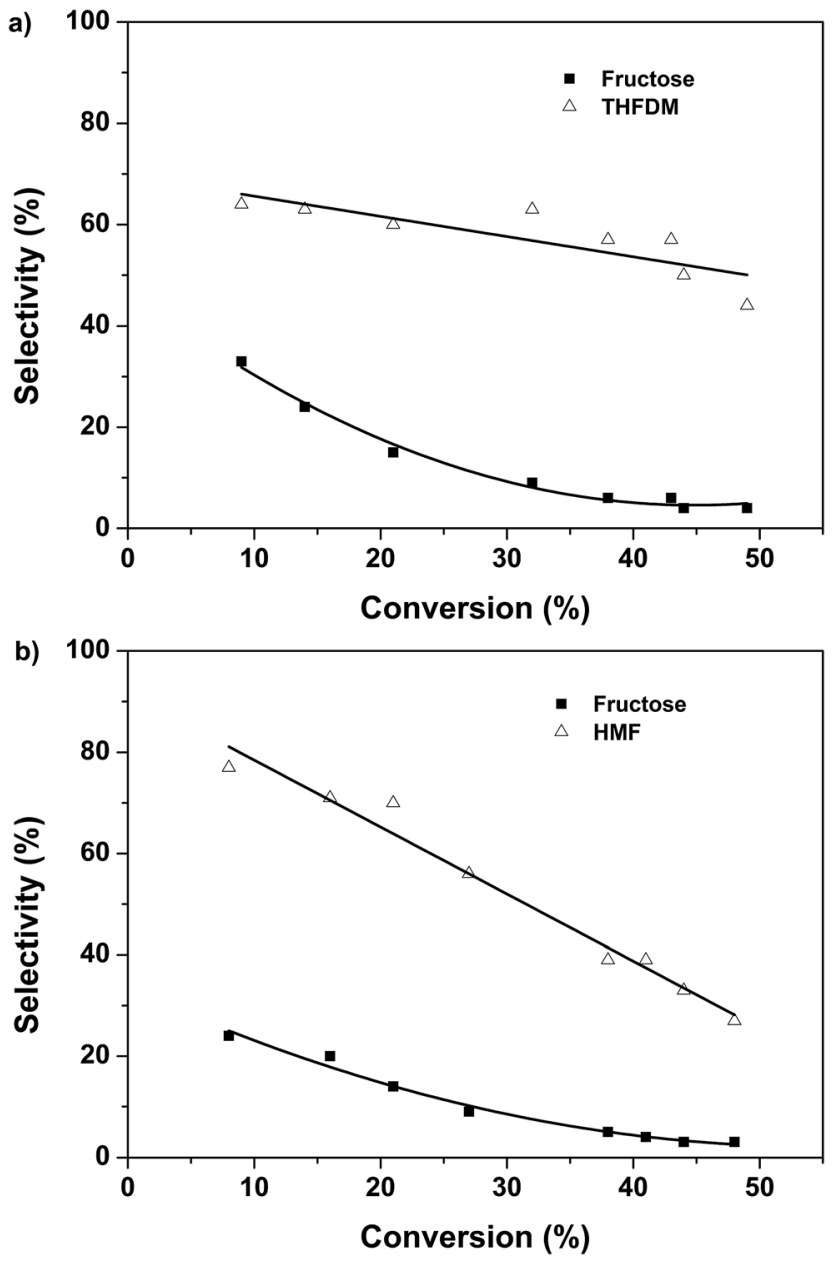

Fig. 3 Products selectivity versus glucose conversion over (a) $\mathrm{Nb}_{2} \mathrm{O}_{5}$ $\mathrm{FP}$ and $\mathrm{Ru} / \mathrm{SiO}_{2}-\mathrm{TM}$, (b) $\mathrm{Nb}_{2} \mathrm{O}_{5}-\mathrm{FP}$. Reaction conditions: $\mathrm{Nb}_{2} \mathrm{O}_{5}-\mathrm{FP}$ (40 $\mathrm{mg})$, glucose aqueous solution ( $3 \mathrm{~mL}$, glucose $1 \mathrm{mmol})$, cyclohexane (6 $\mathrm{mL}$ ), $\mathrm{H}_{2}(4 \mathrm{MPa}), 433 \mathrm{~K} . \mathrm{Ru} / \mathrm{SiO}_{2}-\mathrm{TM}$ (30 mg) for (a).
HMF was not stable and was easy to degrade under this condition. This was in accordance with the results we obtained previously. ${ }^{7}$ The case II was the conversion of glucose to THFDM by the combination of $\mathrm{Nb}_{2} \mathrm{O}_{5}-\mathrm{FP}$ and $\mathrm{Ru} / \mathrm{SiO}_{2}-\mathrm{TM}$. The results at the initial stage were analogous to that of the case I (Fig. 3a). High selectivity of THFDM with quite a number of fructose was obtained. To our delight, the selectivity of THFDM kept around at $60 \%$ with no obviously decrease as the time prolonged (Fig. 3a). This phenomenon was quite different from the selectivity of HMF in the case I. The reason was that the THFDM was much more stable than the HMF. The HMF was converted to THFDM once generated in the case II. As a result, the degradation of HMF was inhibited and the selectivity of THFDM was well kept.

The effect of temperature played an important role in the conversion of glucose and the results were shown in Fig. 4. The conversion of glucose increased as the temperature increased from $413 \mathrm{~K}$ to $453 \mathrm{~K}$ as expected. The selectivity of THFDM kept around $60 \%$ when the temperature was not higher than $433 \mathrm{~K}$. However, once the temperature exceeded $433 \mathrm{~K}$ the selectivity of THFDM decreased drastically. The best result was obtained at a temperature of $433 \mathrm{~K}$. And the reaction was repeated at this temperature. Similar conversion of glucose and selectivity of THFDM was acquired showing the repeatability of the catalytic system.

Fig. 5 showed the recyclability of the catalytic system. After the analysis, ethanol was added into the system to obtain one liquid phase. The catalyst was then centrifuged and fully washed with ethanol after each cycle. After dried at $373 \mathrm{~K}$ under vacuum, the catalyst was used for the next run. It could be seen from Fig. 5 that there had a small gradual decrease in conversion value. This should be ascribed to the incomplete recovery of catalyst after each reaction. The selectivity of THFDM kept around $60 \%$ in all the four consecutive runs. This illustrated the catalyst was stable under the reaction conditions.

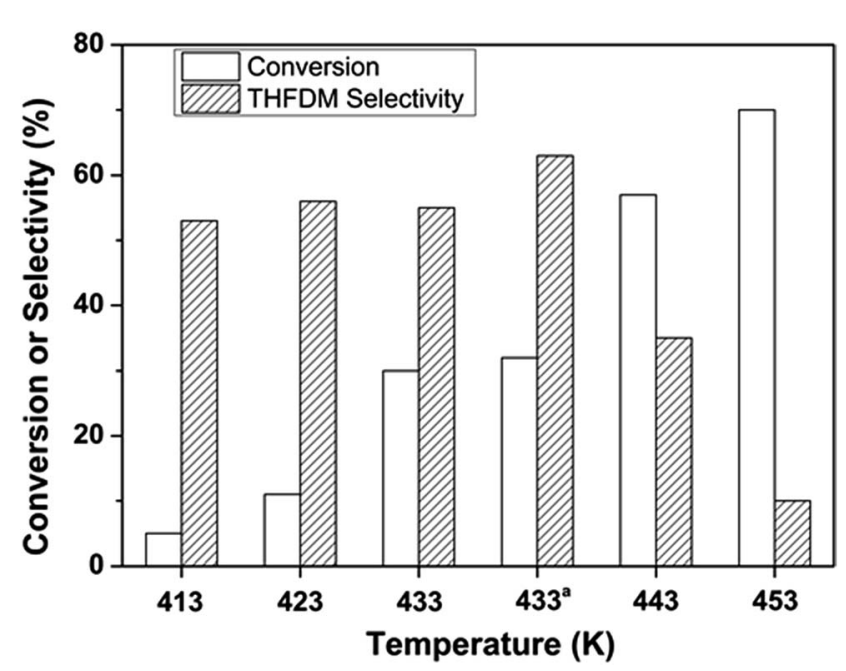

Fig. 4 Effect of temperature on the conversion of glucose to THFDM. ${ }^{a}$ Repeated test for the temperature at $433 \mathrm{~K}$. Reaction conditions: $\mathrm{Nb}_{2} \mathrm{O}_{5}-\mathrm{FP}$ (40 mg), $\mathrm{Ru} / \mathrm{SiO}_{2}-\mathrm{TM}$ (30 mg), glucose aqueous solution (3 $\mathrm{mL}$, glucose $1 \mathrm{mmol})$, cyclohexane $(6 \mathrm{~mL}), \mathrm{H}_{2}(4 \mathrm{MPa}), 433 \mathrm{~K}, 4 \mathrm{~h}$. 


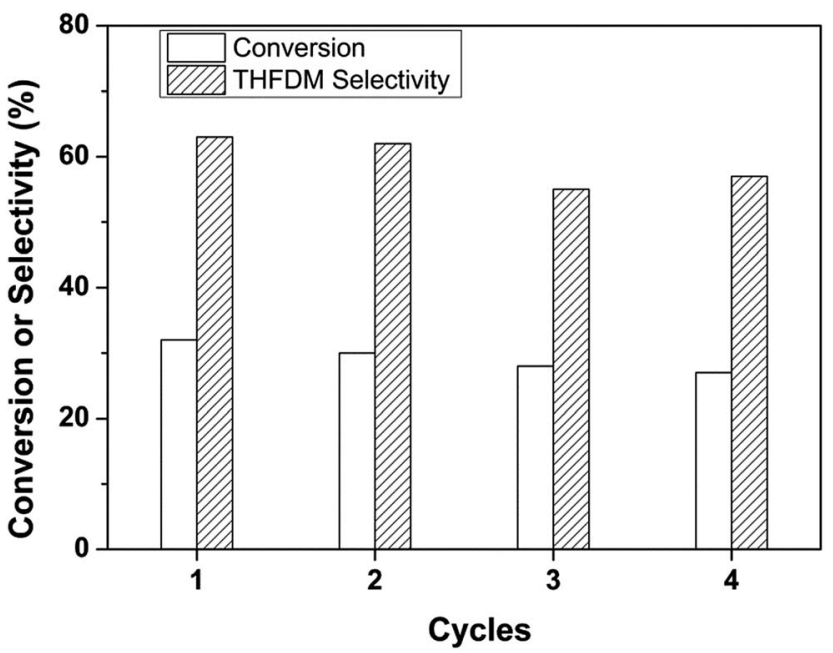

Fig. 5 Cycle experiments of the conversion of glucose to THFDM. Reaction conditions: $\mathrm{Nb}_{2} \mathrm{O}_{5}-\mathrm{FP}(40 \mathrm{mg}), \mathrm{Ru} / \mathrm{SiO}_{2}-\mathrm{TM}(30 \mathrm{mg})$, glucose aqueous solution ( $3 \mathrm{~mL}$, glucose $1 \mathrm{mmol})$, cyclohexane $(6 \mathrm{~mL}), \mathrm{H}_{2}(4$ $\mathrm{MPa}), 433 \mathrm{~K}, 4 \mathrm{~h}$.

We attempted to obtain THFDM directly from carbohydrates, containing glucose or fructose units, by the combination of $\mathrm{Nb}_{2} \mathrm{O}_{5}$-FP and $\mathrm{Ru} / \mathrm{SiO}_{2}$-TM. The fructose was almost completely converted under the reaction condition (Table 1 , entry 2). However, the selectivity of THFDM was only $41 \%$ showed that the conditions adopted here were not appropriate for the conversion of fructose. As a result, the inulin, a polymer consisting of chain-terminating glucosyl moieties and a repetitive fructosyl moiety, gave 33\% selectivity of THFDM although with $96 \%$ of conversion (Table 1 , entry 3). The conversion of sucrose was higher than that of the other two kinds of disaccharides maltose and cellobiose (Table 1, entries 4-6). The reason was that the sucrose was a disaccharide comprised of glucose and fructose while the maltose and cellobiose were comprised of glucose only. The selectivity of THFDM for the three disaccharides was around $40 \%$. The starch, the

Table 1 Conversion of carbohydrates to THFDM ${ }^{a}$

\begin{tabular}{lllllll}
\hline & & \multicolumn{5}{c}{ Selectivity $(\%)$} \\
\cline { 5 - 7 } Entry & Substrate & Conv. $^{b}(\%)$ & THFDM & Fructose & Others $^{c}$ & U. D. $^{d}$ \\
\hline 1 & Glucose & 32 & 63 & 9 & 15 & 13 \\
2 & Fructose & 98 & 41 & 1 & 27 & 31 \\
3 & Inulin & 96 & 33 & 4 & 31 & 32 \\
4 & Sucrose & 61 & 42 & 4 & 25 & 29 \\
5 & Maltose & 37 & 42 & 7 & 22 & 29 \\
6 & Cellobiose & 33 & 32 & 8 & 19 & 41 \\
7 & Starch & 26 & 34 & 11 & 19 & 36
\end{tabular}

${ }^{a}$ Reaction conditions: $\mathrm{Nb}_{2} \mathrm{O}_{5}-\mathrm{FP}(40 \mathrm{mg}), \mathrm{Ru} / \mathrm{SiO}_{2}-\mathrm{TM}(30 \mathrm{mg})$, carbohydrate aqueous solution ( $3 \mathrm{~mL}, 1 \mathrm{mmol}$ by monosaccharide), cyclohexane $(6 \mathrm{~mL}), \mathrm{H}_{2}(4 \mathrm{MPa}), 433 \mathrm{~K}, 4 \mathrm{~h} .{ }^{b}$ Conversion was calculated based on the amounts of monosaccharide. ${ }^{c}$ Others referred to furfuryl alcohol, methyl furfuryl alcohol, $\gamma$-valerolactone, 1,2-pentanediol, 1,2-hexanediol, 1,2,5-hexanetriol, 1,2,6-hexanetriol. ${ }^{d}$ Unidentified products. polysaccharide of glucose, was also able to be converted to THFDM in one-step by this catalytic system. A conversion of $26 \%$ with $34 \%$ selectivity of THFDM was obtained under the same reaction conditions (Table 1 , entry 7 ).

The physical properties of the $\mathrm{Nb}_{2} \mathrm{O}_{5}$-FP were characterized by BET and TEM. The results were shown in Fig. 6 and S3. $†$ The BET surface of as-synthesized $\mathrm{Nb}_{2} \mathrm{O}_{5}$-FP was $62 \mathrm{~m}^{2} \mathrm{~g}^{-1}$. According to the IUPAC classifications, the sample had the characteristics of typical type IV physisorption isotherms, indicating the presence of mesoporous structure. There had a significantly increase in adsorbed volume at relatively high pressure which was the characteristic of the H3 type hysteresis loop indicating the existence of slit-shaped pores with a large pore size which was in accordance with the results of TEM. The distribution of pore size calculated by the non-local density functional theory (NLDFT) model showed there had very broad pore size distribution in the mesoporous range $(2-50 \mathrm{~nm})$ and macropore were also presented in the $\mathrm{Nb}_{2} \mathrm{O}_{5}-\mathrm{FP}$.

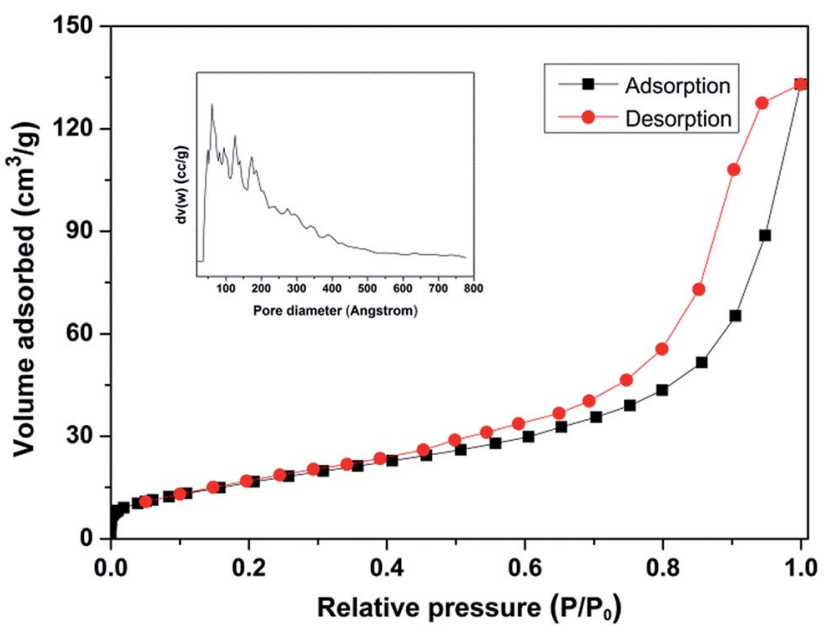

Fig. $6 \mathrm{~N}_{2}$ adsorption/desorption isotherms of $\mathrm{Nb}_{2} \mathrm{O}_{5}-\mathrm{FP}$.

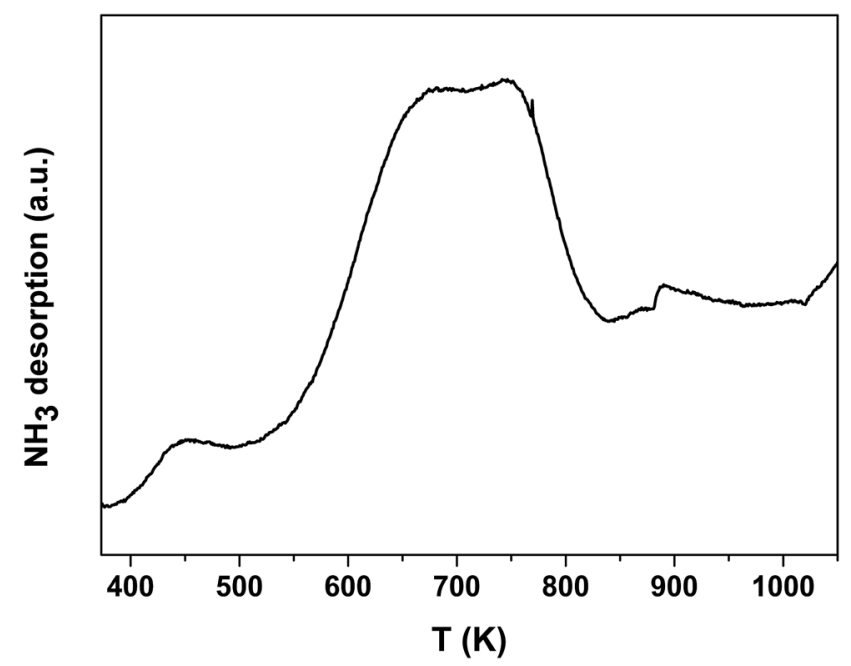

Fig. $7 \mathrm{NH}_{3}-\mathrm{TPD}$ profiles of $\mathrm{Nb}_{2} \mathrm{O}_{5}-\mathrm{FP}$. 


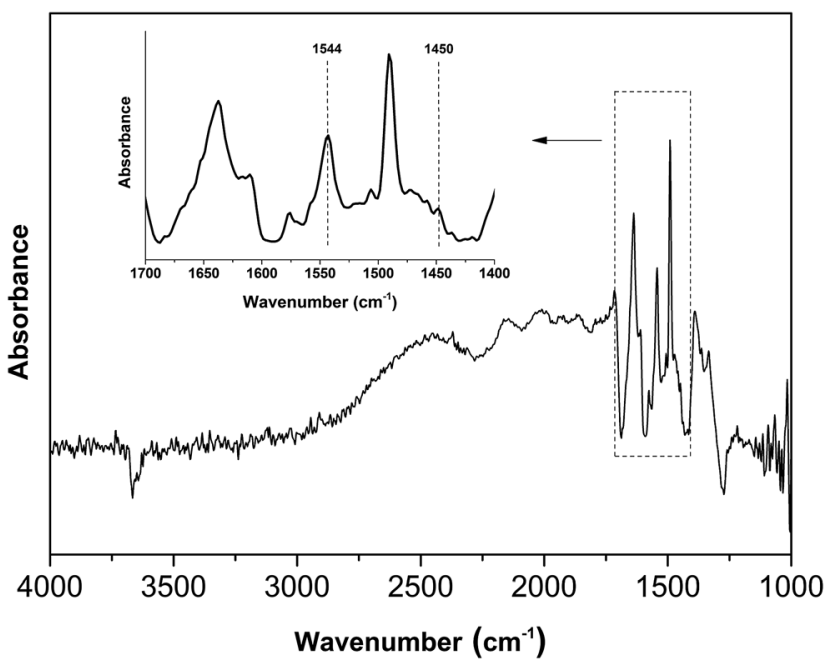

Fig. 8 FT-IR spectrum of $\mathrm{Nb}_{2} \mathrm{O}_{5}-\mathrm{FP}$ after pyridine adsorption and subsequent evacuation, the sample was treated in vacuum to remove adsorbed water.

The acid property of the $\mathrm{Nb}_{2} \mathrm{O}_{5}$-FP was characterized by temperature-programmed desorption of ammonia ( $\left.\mathrm{NH}_{3}-\mathrm{TPD}\right)$ (Fig. 7) as well as Fourier transform infrared (FT-IR) spectroscopy of adsorbed pyridine (Fig. 8). There were two desorption peaks appeared in the $\mathrm{NH}_{3}$-TPD profile. The weak desorption peak at low temperature (400-500 K) should be ascribed to the weakly held ammonia, probably the hydrogen-bonded ammonia according to the literature. ${ }^{60}$ The strong broad desorption peak between 600 and $800 \mathrm{~K}$ corresponded to large amount of the medium and the strong acid sites in the sample. The FT-IR spectroscopy of adsorbed pyridine revealed the type of the acid sites. ${ }^{61,62}$ The medium peak at $1544 \mathrm{~cm}^{-1}$ was attributed to pyridine protonated on Brönsted sites, and the weak peak at $1450 \mathrm{~cm}^{-1}$ indicated the presence of Lewis acid sites. The peak intensity at $1544 \mathrm{~cm}^{-1}$ and $1450 \mathrm{~cm}^{-1}$ elucidated that the sample had a very high Brönsted/Lewis ratio. And the high Brönsted/Lewis ratio was favourable for high selectivity of HMF from glucose in the aqueous phase. ${ }^{63}$

\section{Conclusions}

In conclusion, the direct conversion of a wide variety of carbohydrates to THFDM was achieved by the combination of $\mathrm{Nb}_{2} \mathrm{O}_{5}$ $\mathrm{FP}$ and $\mathrm{Ru} / \mathrm{SiO}_{2}-\mathrm{TM}$ in the water/cyclohexane biphasic system. The as-synthesized $\mathrm{Nb}_{2} \mathrm{O}_{5}-\mathrm{FP}$, which was proved to have large amount of medium and strong acid sites with high Brönsted/ Lewis ratio, was essential and effective for keeping high THFDM selectivity when glucose was used as substrate. This work provides a common strategy for the direct production of valuable chemicals from carbohydrates.

\section{Acknowledgements}

This work was supported by the National Natural Science Foundation of China (21272109 and 21371089) and the
Intercollegiate Key Scientific Research Projects of Henan Province (16A150017). The authors express their gratitude for the help and guidance from Researcher Jie Xu at Dalian Institute of Chemical Physics, Chinese Academy of Sciences.

\section{References}

1 M. Besson, P. Gallezot and C. Pinel, Chem. Rev., 2014, 114, 1827-1870.

2 D. Chen, F. Liang, D. Feng, F. Du, G. Zhao, H. Liu and M. Xian, Catal. Commun., 2016, 84, 159-162.

3 A. Corma, S. Iborra and A. Velty, Chem. Rev., 2007, 107, 24112502.

4 J. Ma, W. Yu, M. Wang, X. Jia, F. Lu and J. Xu, Chin. J. Catal., 2013, 34, 492-507.

5 A. M. Ruppert, K. Weinberg and R. Palkovits, Angew. Chem., Int. Ed., 2012, 51, 2564-2601.

6 R. J. van Putten, J. C. van der Waal, E. de Jong, C. B. Rasrendra, H. J. Heeres and J. G. de Vries, Chem. Rev., 2013, 113, 1499-1597.

7 Y. Yang, Z. Du, J. Ma, F. Lu, J. Zhang and J. Xu, ChemSusChem, 2014, 7, 1352-1356.

8 Y.-R. Zhang, N. Li, M.-F. Li and Y.-M. Fan, RSC Adv., 2016, 6, 21347-21351.

9 Y. Zhang, Y. Chen, Y. Shen, Y. Yan, J. Pan, W. Shi and L. Yu, ChemPlusChem, 2016, 81, 108-118.

10 P. Zhou and Z. Zhang, Catal. Sci. Technol., 2016, 6, 36943712.

$11 \mathrm{X} . \mathrm{Hu}, \mathrm{R} . \mathrm{J} . \mathrm{M}$. Westerhof, D. Dong, L. Wu and C.-Z. Li, ACS Sustainable Chem. Eng., 2014, 2, 2562-2575.

12 J. P. Lange, E. van der Heide, J. van Buijtenen and R. Price, ChemSusChem, 2012, 5, 150-166.

13 J. Zhang, J. Zhuang, L. Lin, S. Liu and Z. Zhang, Biomass Bioenergy, 2012, 39, 73-77.

14 D. Ding, J. Wang, J. Xi, X. Liu, G. Lu and Y. Wang, Green Chem., 2014, 16, 3846-3853.

15 R. Weingarten, Y. T. Kim, G. A. Tompsett, A. Fernández, K. S. Han, E. W. Hagaman, W. C. Conner, J. A. Dumesic and G. W. Huber, J. Catal., 2013, 304, 123-134.

16 K. Fulajtárova, T. Soták, M. Hronec, I. Vávra, E. Dobročka and M. Omastová, Appl. Catal., A, 2015, 502, 78-85.

17 A. B. Merlo, V. Vetere, J. F. Ruggera and M. L. Casella, Catal. Commun., 2009, 10, 1665-1669.

18 Q. Yuan, D. Zhang, L. V. Haandel, F. Ye, T. Xue, E. J. M. Hensen and Y. Guan, J. Mol. Catal. A: Chem., 2015, 406, 58-64.

19 M. Manikandan, A. K. Venugopal, A. S. Nagpure, S. Chilukuri and T. Raja, RSC Adv., 2016, 6, 3888-3898.

20 F. Wang and Z. Zhang, ACS Sustainable Chem. Eng., 2017, 5, 942-947.

21 Y. Nakagawa, H. Nakazawa, H. Watanabe and K. Tomishige, ChemCatChem, 2012, 4, 1791-1797.

22 Y. Yang, J. Ma, X. Jia, Z. Du, Y. Duan and J. Xu, RSC Adv., 2016, 6, 51221-51228.

23 Y. Roman-Leshkov, C. J. Barrett, Z. Y. Liu and J. A. Dumesic, Nature, 2007, 447, 982-985. 
24 S. Siankevich, G. Savoglidis, Z. Fei, G. Laurenczy, D. T. L. Alexander, N. Yan and P. J. Dyson, J. Catal., 2014, 315, 67-74.

25 Y. Liu, L. Zhu, J. Tang, M. Liu, R. Cheng and C. Hu, ChemSusChem, 2014, 7, 3541-3547.

26 J. Nie, J. Xie and H. Liu, J. Catal., 2013, 301, 83-91.

27 J. Chen, Y. Guo, J. Chen, L. Song and L. Chen, ChemCatChem, 2014, 6, 3174-3181.

28 R. Liu, J. Chen, L. Chen, Y. Guo and J. Zhong, ChemPlusChem, 2014, 79, 1448-1454.

29 N. Mittal, G. M. Nisola, L. B. Malihan, J. G. Seo, H. Kim, S.-P. Lee and W.-J. Chung, RSC Adv., 2016, 6, 25678-25688.

30 M. Chatterjee, T. Ishizaka, A. Chatterjee and H. Kawanami, Green Chem., 2017, 19, 1315-1326.

31 G. Li, Z. Sun, Y. Yan, Y. Zhang and Y. Tang, ChemSusChem, 2017, 10, 494-498.

32 Y. Yang, Z. Du, Y. Huang, F. Lu, F. Wang, J. Gao and J. Xu, Green Chem., 2013, 15, 1932-1940.

33 G.-S. Zhang, M.-M. Zhu, Q. Zhang, Y.-M. Liu, H.-Y. He and Y. Cao, Green Chem., 2015, 18, 2155-2164.

34 L. Deng, Y. Zhao, J. Li, Y. Fu, B. Liao and Q. X. Guo, ChemSusChem, 2010, 3, 1172-1175.

35 R. V. Maligal-Ganesh, C. Xiao, T. W. Goh, L.-L. Wang, J. Gustafson, Y. Pei, Z. Qi, D. D. Johnson, S. Zhang, F. Tao and W. Huang, ACS Catal., 2016, 6, 1754-1763.

36 V. V. Kumar, G. Naresh, M. Sudhakar, C. Anjaneyulu, S. K. Bhargava, J. Tardio, V. K. Reddy, A. H. Padmasri and A. Venugopal, $R S C A d v .$, 2016, 6, 9872-9879.

37 J. Chen, R. Liu, Y. Guo, L. Chen and H. Gao, ACS Catal., 2015, 5, 722-733.

38 Y. Guo and J. Chen, RSC Adv., 2016, 6, 101968-101973.

39 K. Chen, M. Tamura, Z. Yuan, Y. Nakagawa and K. Tomishige, ChemSusChem, 2013, 6, 613-621.

40 S. Liu, M. Tamura, Y. Nakagawa and K. Tomishige, ACS Sustainable Chem. Eng., 2014, 2, 1819-1827.

41 S. Liu, Y. Okuyama, M. Tamura, Y. Nakagawa, A. Imai and K. Tomishige, Green Chem., 2016, 18, 165-175.

42 Y. Weng, S. Qiu, C. Wang, L. Chen, Z. Yuan, M. Ding, Q. Zhang, L. Ma and T. Wang, Fuel, 2016, 170, 77-83.

43 Y. Liu, L. Chen, T. Wang, Q. Zhang, C. Wang, J. Yan and L. Ma, ACS Sustainable Chem. Eng., 2015, 3, 1745-1755.
44 Q. Xia, Z. Chen, Y. Shao, X. Gong, H. Wang, X. Liu, S. F. Parker, X. Han, S. Yang and Y. Wang, Nat. Commun., 2016, 7, 11162-11171.

45 W. Yang and A. Sen, ChemSusChem, 2011, 4, 349-352.

46 B. Op de Beeck, M. Dusselier, J. Geboers, J. Holsbeek, E. Morré, S. Oswald, L. Giebeler and B. F. Sels, Energy Environ. Sci., 2015, 8, 230-240.

47 B. Liu and Z. Zhang, ChemSusChem, 2016, 9, 2015-2036.

48 T. Buntara, S. Noel, P. H. Phua, I. Melian-Cabrera, J. G. de Vries and H. J. Heeres, Angew. Chem., Int. Ed., 2011, 50, 7083-7087.

49 B. Xiao, M. Zheng, X. Li, J. Pang, R. Sun, H. Wang, X. Pang, A. Wang, X. Wang and T. Zhang, Green Chem., 2016, 18, 2175-2184.

50 W. Xu, H. Wang, X. Liu, J. Ren, Y. Wang and G. Lu, Chem. Commun., 2011, 47, 3924-3926.

51 S. Koso, I. Furikado, A. Shimao, T. Miyazawa, K. Kunimori and K. Tomishige, Chem. Commun., 2009, 15, 2035-2037.

52 S. P. Burt, K. J. Barnett, D. J. McClelland, P. Wolf, J. A. Dumesic, G. W. Huber and I. Hermans, Green Chem., 2017, 19, 1390-1398.

53 Y. Nakagawa, M. Tamura and K. Tomishige, Catal. Surv. Asia, 2015, 19, 249-256.

54 S. Liu, Y. Amada, M. Tamura, Y. Nakagawa and K. Tomishige, Green Chem., 2014, 16, 617-626.

55 Y. Nakagawa and K. Tomishige, Catal. Today, 2012, 195, 136143.

56 S. Liu, Y. Okuyama, M. Tamura, Y. Nakagawa, A. Imai and K. Tomishige, ChemSusChem, 2015, 8, 628-635.

57 C. Moreaua, M. N. Belgacemb and A. Gandini, Top. Catal., 2004, 35, 11-30.

58 S. Koso, H. Watanabe, K. Okumura, Y. Nakagawa and K. Tomishige, Appl. Catal., B, 2012, 111-112, 27-37.

59 K. Nakajima, Y. Baba, R. Noma, M. Kitano, J. N. Kondo, S. Hayashi and M. Hara, J. Am. Chem. Soc., 2011, 133, 4224-4227.

60 T. Miyamoto, N. Katada, J.-H. Kim and M. Niwa, J. Phys. Chem. B, 1998, 102, 6738-6745.

61 M. C. Kung and H. H. Kung, Catal. Rev., 1985, 27, 425-460.

62 B. A. Morrow and I. A. Cody, J. Phys. Chem., 1976, 80, 19951998.

63 V. V. Ordomsky, V. L. Sushkevich, J. C. Schouten, J. van der Schaaf and T. A. Nijhuis, J. Catal., 2013, 300, 37-46. 